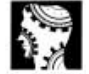

original papers
MOHAMMAD, A. M., FINEBERG, N. A., \&RUMMOND, L. M. (2000)

Obsessive-compulsive disorder Medicine, 28, 15-16.

NATIONAL INSTITUTE FOR HEALTHAND CLINICAL EXCELLENCE (2006)

Obsessive-Compulsive Disorder: Care Interventions in the Treatment of Obsessive-Compulsive Disorder and Body Dysmorphic Disorder.
NICE. http://www.nice.org.uk/ page. $a s p x ? 0=289817$

SANAVIO, E. (1988) Obsessions and compulsions: The Padua Inventory. Behaviour Research and Therapy, 26,169-177.

WETZEL, C., BENTS, H., \& FLORIN, I. (1999) High-density exposure therapy for obsessive-compulsive inpatients: a 1-year follow-up. Psychotherapy and Psychosomatics, 68, 186-193.

WORLDHEALTHORGANIZATION (1992) The ICD-10 Classification of Mental Descriptions and Diagnostic Guidelines. World Health Organization.

*Lynne M. Drummond Consultant Psychiatrist and Senior Lecturer in Behavioural Cognitive Psychotherapy, St George's, University of London, London SW17ORE, email: lynnemd@sgul.ac.uk, AnushaPillay Cognitive-Behavioural Psychotherapist, Peter Kolb Cognitive-Behavioural Psychotherapist, Shashi Rani Associate Specialist, Behavioural Cognitive Psychotherapy Unit Springfield University Hospital, London SW17 7DJ

\title{
Protecting patients in psychiatric care: the St Andrew's Human Rights Project
}

\section{AIMS AND METHOD}

The Human Rights Act was incorporated into UK law in 2000, but little is known about how it is implemented in psychiatric care. We explored the understanding of multidisciplinary teams of the restriction and protection of patients' human rights using an open-response questionnaire. Content analysis was employed to summarise written, narrative data about the human rights of 102 patients in secure psychiatric care.
RESULTS

Our clinical teams considered human rights to be protected through risk assessment and management, ongoing monitoring, local policy and existing UK mental health legislation. Understanding of the proper and proportionate restriction of 'qualified' rights (such as article 5 liberty) and the positive enablement and promotion of human rights (such as article 8 family and private life) appeared to be limited.

\section{CLINICAL IMPLICATIONS}

A cultural shift in focus is required in mental health services to understand and ensure positive promotion of human rights. Clinicians should directly address the human rights of their patients and articulate the rationale for proportionate restrictions of qualified rights. Clinical policy, training and audit should explicitly embody the protection of human rights.
The Human Rights Act 1998 was incorporated into UK law in October 2000 and ratified the rights outlined in the European Convention on Human Rights. There has been a recent focus on new mental health detention legislation and the Convention right to liberty (Sugarman, 2002), but of course all the rights of the Convention apply to those in psychiatric care. The Act applies to employees of public authorities, including hospitals providing care under the Mental Health Act 1983. Patients may now attempt to enforce their rights in the domestic courts (Macgregor-Morris et al, 2001).

However, there is little evidence, as yet, of an upsurge of legal challenges (Bowen, 2004).

Rights conferred under the Act are 'absolute' or 'qualified'. Absolute rights cannot be infringed by any public authority, however necessary this may appear. Qualified rights may be restricted proportionately to promote specific, legitimate aims, including public safety. Crucially, the Act requires public authorities to actively promote Convention rights.

Limited evidence is available on clinicians' knowledge of the Act, its implementation, or the active promotion of rights in psychiatric practice. Passmore \& Leung (2003) reported that psychiatrists have good overall knowledge of the Act, but there may be a gap between the awareness of senior clinicians and implementation by clinical teams. Similarly, the British Institute of Human Rights
(2002) reported good awareness of the existence of the Act among providers of services for people with disabilities, but little knowledge of how this relates to practice. In the current study we explored how the Act applies in practice by investigating the understanding within clinical teams of the statutory and local devices that will aid protection and, where appropriate, justify the proportionate restriction of their patients' human rights.

\section{Method}

\section{Study design}

In order to audit our clinical practice, we sought written, narrative descriptions of the proportionate restriction of the qualified human rights of patients and the protection of both their absolute and qualified human rights utilising an open-response questionnaire. We reviewed the literature and relevant case law to generate pertinent issues (see Tables 1 and 2). For each identified issue we asked how protection for each patient was ensured and, for qualified rights, whether any proportionate restrictions were in place for this patient. Our instruction was for the questionnaire to be completed by each patient's care programme approach (CPA) coordinator in consultation with the multidisciplinary team. Questionnaires were 


\begin{tabular}{|c|c|c|c|}
\hline $\begin{array}{l}\text { Human Rights } \\
\text { Act } 1998 \text { article }\end{array}$ & Case law issue & Reported methods of protection & $\begin{array}{l}\text { Responses } \\
\text { citing this } \\
\text { method of } \\
\text { protection, \% }\end{array}$ \\
\hline \multirow{7}{*}{$\begin{array}{l}\text { Article 2, } \\
\text { right to life }\end{array}$} & \multirow[t]{3}{*}{ Suicide prevention } & Individual risk assessment and management & 71 \\
\hline & & Assess patient's history of suicidal behaviour & 46 \\
\hline & & General and close levels of observation & 33 \\
\hline & \multirow{4}{*}{$\begin{array}{l}\text { Protection from other } \\
\text { potentially dangerous } \\
\text { patients }\end{array}$} & Individual risk assessment and management & 50 \\
\hline & & Assess patient's history of vulnerability to bullying or intimidation & 12 \\
\hline & & Assess patient's history of behaviours likely to provoke others & 9 \\
\hline & & Ongoing monitoring & 17 \\
\hline \multirow{17}{*}{$\begin{array}{l}\text { Article 3, } \\
\text { protection from } \\
\text { inhumane and } \\
\text { degrading } \\
\text { treatment }\end{array}$} & \multirow{4}{*}{$\begin{array}{l}\text { Proper justification for } \\
\text { the use of control and } \\
\text { restraint }\end{array}$} & Individual risk assessment and management & 74 \\
\hline & & Individualised assessment for restraint & 62 \\
\hline & & Assessment of presence/absence of behaviours necessitating restraint & 67 \\
\hline & & Adherence to hospital restraint policy & 63 \\
\hline & \multirow{2}{*}{$\begin{array}{l}\text { Justification of use of } \\
\text { other forcible mea- } \\
\text { sures, e.g. medication }\end{array}$} & Assessment of current medication adherence & 43 \\
\hline & & Mental Health Act 1983 form 38/39 SOAD system & 24 \\
\hline & \multirow{6}{*}{$\begin{array}{l}\text { Appropriate use of } \\
\text { seclusion } \\
\text { Need for single sex } \\
\text { accommodation }\end{array}$} & Individual risk assessment and management & 14 \\
\hline & & Hospital seclusion policy & 27 \\
\hline & & Use of single sex accommodation as default & 73 \\
\hline & & Consideration of requests made by patients & 11 \\
\hline & & Individual risk assessment & 43 \\
\hline & & Hospital complaints procedure & 21 \\
\hline & \multirow{5}{*}{$\begin{array}{l}\text { Protection against ill } \\
\text { treatment/ sexual } \\
\text { exploitation } \\
\text { Participation in } \\
\text { research }\end{array}$} & Investigation of patient reports of exploitation & 6 \\
\hline & & Individual risk assessment, particularly history of vulnerability to exploitation & 6 \\
\hline & & Interventions to manage the presence of sexually predatory patients & 4 \\
\hline & & Hospital procedures/policies regarding research & 18 \\
\hline & & Assessment of capacity & 2 \\
\hline
\end{tabular}

SOAD, second opinion approved doctor.

collected together with anonymised patient details (gender, age, length of hospitalisation, legal status).

\section{Participants}

Questionnaires were sent to seven medically led multidisciplinary care teams employed in the 118-bed adult mental health division of St Andrew's Hospital, Northampton, a charitable provider of specialist mental healthcare and rehabilitation. Our instruction was for participation to be a team exercise, with team views summarised on open-response questionnaires by CPA coordinators. The CPA coordinators summarising the team view included 62 psychiatric nurses and five occupational therapists.

\section{Data analysis}

Data were analysed by quantitative content analysis (Neuendorf, 2001). Written, narrative data were screened to generate broad categories of rights restriction and protection. We subsequently assigned narrative data from all questionnaires into these categories.

\section{Results}

Questionnaires were collected for 102 of 118 (86.4\%) patients; 71 patients (69.6\%) were male and 31 (30.4\%) female. The mean length of in-patient stay was 48.9 months; 94 (92.2\%) patients were detained.

Table 1 shows how absolute human rights were largely described as being protected through individualised risk assessment and management. Few details were given of how specifically this might protect rights. In addition, local policy was cited as protecting patients against unjustified use of restraint and seclusion. National legislation, mainly the Mental Health Act 1983, was viewed as one of two main methods of protecting against forcible measures such as tranquillisation.

Table 2 illustrates the narrow extent to which respondents viewed the qualified human rights of patients as being restricted. The most frequent restriction was reported to be hospitalisation away from the patient's home area (12 patients). Smaller numbers of patients were reported to have their rights restricted in terms of privacy (7 patients), contact with family ( 5 patients) and mail and telephone contact (1 patient). Again, local policy and national legislation were among the most frequently cited methods of protection, although individualised risk assessment was not.

\section{Discussion}

We studied the understanding of multidisciplinary teams of how human rights are protected and, for qualified 
Table 2. Reported methods of protection and restriction of qualified human rights

original papers
Patients

\begin{tabular}{|c|c|c|c|c|}
\hline $\begin{array}{l}\text { Human Rights } \\
\text { Act } 1998 \text { article }\end{array}$ & Case law issue & $\begin{array}{l}\text { restricted, } \\
n(\%)\end{array}$ & $\begin{array}{l}\text { Methods of/reasons for } \\
\text { restriction }\end{array}$ & Methods of protection \\
\hline \multirow[t]{3}{*}{$\begin{array}{l}\text { Article } 5 \text {, right } \\
\text { to liberty and } \\
\text { security of } \\
\text { person }\end{array}$} & $\begin{array}{l}\text { Information about reasons } \\
\text { for detention }\end{array}$ & $2(2)$ & & $\begin{array}{l}\text { Mental Health Act section } 132 \\
\text { information. Identification of } \\
\text { named individual to explain } \\
\text { rights (CPA coordinator) }\end{array}$ \\
\hline & $\begin{array}{l}\text { Access to speedy legal } \\
\text { representation in private }\end{array}$ & $0 \quad(0)$ & & $\begin{array}{l}\text { Hospital Mental Health Act } \\
\text { policy, access to } \\
\text { advocacy service }\end{array}$ \\
\hline & $\begin{array}{l}\text { Access to legal proceedings } \\
\text { to test detention }\end{array}$ & $0 \quad(0)$ & & $\begin{array}{l}\text { Hospital Mental Health Act } \\
\text { policy }\end{array}$ \\
\hline \multirow{5}{*}{$\begin{array}{l}\text { Article } 8 \text {, right } \\
\text { to respect for } \\
\text { private and } \\
\text { family life }\end{array}$} & Mail and telephone contact & 1 (1) & $\begin{array}{l}\text { Routine checking of mail on } \\
\text { some wards/for some } \\
\text { patients }\end{array}$ & \\
\hline & $\begin{array}{l}\text { Privacy - bodily } \\
\text { Personal space/room }\end{array}$ & $7 \quad(7)$ & $\begin{array}{l}\text { Close observation, no access } \\
\text { to room at certain times }\end{array}$ & \\
\hline & Contact with family & $5 \quad(5)$ & $\begin{array}{l}\text { Owing to family being previous } \\
\text { victims }\end{array}$ & \\
\hline & $\begin{array}{l}\text { Hospitalisation close to home } \\
\text { area }\end{array}$ & $12(12)$ & $\begin{array}{l}\text { Home health authority unable } \\
\text { to provide suitable accommo- } \\
\text { dation }\end{array}$ & $\begin{array}{l}\text { Efforts of clinical team to } \\
\text { ensure contact maintained }\end{array}$ \\
\hline & Confidentiality & $0 \quad(0)$ & & Hospital policy \\
\hline $\begin{array}{l}\text { Article 10, } \\
\text { freedom of } \\
\text { expression }\end{array}$ & $\begin{array}{l}\text { Opportunity to publish } \\
\text { (including internet) }\end{array}$ & $0 \quad(0)$ & $\begin{array}{l}\text { Usually described as } \\
\text { 'not applicable or not relevant' }\end{array}$ & \\
\hline $\begin{array}{l}\text { Article } 12 \text {, right } \\
\text { to marry and } \\
\text { found a family }\end{array}$ & Conjugal visits from spouse & $0 \quad(0)$ & $\begin{array}{l}\text { Usually described as not } \\
\text { applicable as patient has no } \\
\text { spouse }\end{array}$ & \\
\hline
\end{tabular}

rights, restricted in secure psychiatric care. Absolute rights were largely described as being protected by existing UK legislation, organisational policy, individualised risk assessment and risk management. Qualified rights were rarely viewed as being restricted in this population of mostly detained patients.

It has previously been suggested that the Human Rights Act 1998 would have an impact on suicide prevention policies (Persaud \& Hewitt, 2001) and lead to a greater emphasis on risk assessment, which seems consistent with our findings. There is an identified need for more regular training in risk assessment for staff, but also explicit guidance on staffing levels and observation (Hewson, 2000). Our clinicians focused on risk management, but they did not cite training or staffing issues. Although this might not be an area of concern for them, their understanding of the relevance of human rights law to clinical practice may be limited.

Our study shows that practitioners naturally refer to the Mental Health Act 1983 on issues of enforced medication. The focus on risk management was accompanied by little on patients' positive capacity, or a person's previously expressed preferences (Wong et al, 1999), suggesting the Mental Capacity Act 2005 has had little impact so far. There was similarly little on positive protections under the Care Standards Act 2000 (Jones, 2004), or the CPA in protection of article 8 rights, even though this is routinely addressed. Restrictions of article
10 (patient access to published material) and article 12 (conjugal visits) rights were also not raised, although these issues can clearly lead to complex ethical dilemmas (e.g. Persaud \& Hewitt, 2001). Our staff do appear to think of human rights in a narrow 'risk assessment' way, separate from much of their more enabling clinical work.

\section{Potential criticisms}

The protection of human rights in psychiatric care is currently largely undescribed, necessitating an exploratory methodology to map the area. The method of data collection utilised in this study therefore imposes some limitations on its findings: themes were generated from written, narrative data provided and we did not offer prompts as to 'correct' answers. In addition, we cannot gauge the degree of multidisciplinary communication, although our instruction was for completion to be a team exercise within our medically led teams. We did not attempt to assess the knowledge level of particular professions, as the data are based on the team view as perceived by CPA coordinators. However, evidence suggests that different professional groups may view certain legal applications quite differently (e.g. Peay, 2003), and further research could investigate how this affects team decision-making in relation to human rights protection. Finally, the study was undertaken in a psychiatric hospital in the independent sector and find- 
ings cannot necessarily be generalised to National Health Service (NHS) settings, although most of our clinical staff move between the NHS and the independent sector at some point in their careers.

\section{Implications}

The challenge of modern healthcare governance in a complex regulatory environment is to integrate statutory requirements of different kinds into a coherent body of clinical policy and best practice. At present our clinical policies have become dominated by the requirement of the Healthcare Commission under the Care Standards Act 2000 and the Mental Health Act 1983, with associated instruments such as the National Minimum Care Standards and the Mental Health Act Code of Practice. The Human Rights Act 1998 is a framework of principle against which other statutes are now measured. There is a clear need to develop a culture of healthcare governance which has human rights at its heart, explicitly expressed throughout clinical policy, training and audit.

\section{References}

BOWEN, P. (2004) Is this a revolution? The impact of the Human Rights Act on Mental Health Law. Journal of Mental Health Law, February, 27-34.

BRITISH INSTITUTE OF HUMAN RIGHTS (2002) Something for Everyone: The Impact of the Human Rights Act and the Need for a Human Rights Commission. British Institute of Human Rights.

HEWSON, B. (2000) Why the Human Rights Act matters to doctors. BMJ, 321, 780-781.

JONES, R. (2004) Care Standards Manual. Sweet \& Maxwell.

MacGREGOR-MORRIS, R., EWBANK, J. \& BIRMINGHAM, L. (2001) Potential impact of the Human Rights Act on psychiatric practice: the best of British values? BMJ, 322, 848-850.

NEUENDORF, K. A. (2001) The Content Analysis Guidebook. Sage.
PASSMORE, K. \& LEUNG, W. C. (2003) Psychiatrists' knowledge of the Human Rights Act and its relevance to mental health practice: a questionnaire survey. Medicine, Science and the Law, $\mathbf{4 3}$ 136-140.

\section{PEAY, J. (2003) Decisions and}

Dilemmas: Working with Mental Health Law. Hart Publishing.

PERSAUD, A. \& HEWITT, D. (2001) European Convention on Human Rights: effects on psychiatric care. Nursing Standard, 15, 33-37.

SUGARMAN, P. (2002). Persons of unsound mind, dangerousness and the Human Rights Act 1998. Journal of Forensic Psychiatry, 13, 569-577.

WONG, J.G., CLARE, I. C. H., GUNN, M. J., et al (1999) Capacity to make health care decisions: its importance in clinical practice. Psychological Medicine, 29, 437-446.

\section{Declaration of interest}

\section{Researching recovery from psychosis: a user-led project}

\section{AIMS AND METHOD}

Involvement of service users in the research process and examination of recovery from psychosis are two topics that have generated recent interest within the research community. This user-led study examines the subjective experience of recovery in people with experience of psychosis. Seven interviews were analysed using interpretative

\author{
phenomenological analysis and \\ several themes emerged from the \\ data. \\ RESULTS \\ Recovery from psychosis was found \\ to be a complex and idiosyncratic \\ process, which often involved \\ rebuilding life, rebuilding self and \\ hope for a better future (each of \\ these themes consisted of sub- \\ themes).
}

\author{
CLINICAL IMPLICATIONS \\ The importance of continuity of \\ care, the need for greater choice in \\ approaches aimed at alleviating \\ distress, access to stories of recovery \\ and encouragement, and the \\ importance of more individualised \\ recovery care plans are among \\ factors highlighted.
}

The involvement of service users in research is increasingly acknowledged as important within the mental health field. The term 'user-led research' refers to research where service users control all stages of the research process, including design, data collection and analysis, writing-up and dissemination (Rose, 2003). Service users, rather than being the objects of research, become active agents in decisions about the research process. This benefits the research by ensuring that the work done is relevant to the concerns of service users. In addition, the rapport developed by user interviewers can lead to the collection of data not otherwise accessible.
The research outlined in this paper was conducted by two user researchers (L.P. and M.K.). They met regularly with a steering committee of further service users and together they made decisions about the topic and design of the study, and conducted all stages of the research into recovery from psychosis. Research supervision was provided by clinical psychologists (S.N., M.W. and A.P.M.) with experience of research methods, data analysis and dissemination of research findings.

With increasing interest in the concept of recovery from psychosis it is useful to examine the background to this. Historically, the application of the medical approach, 